\title{
Effect of acetoacetate on urinary excretion of xanthurenic acid and other tryptophan metabolites in rats
}

\author{
By M. C. NATH AND N. V. SHASTRI \\ University Department of Biochemistry, Nagpur-I, India \\ (Received 15 Fuly I968-Accepted 30 October 1968)
}

\begin{abstract}
1. An experiment was performed to study the effect of sodium acetoacetate on urinary excretion of xanthurenic acid and other tryptophan metabolites in male albino rats.

2. Animals were fed on a nicotinic acid-deficient diet for a period of 3 weeks. The animals were then divided into two groups and, after the basal urinary excretion of the tryptophan metabolites had been estimated, the rats of both the groups were force-fed with L-tryptophan (Ioo $\mathrm{mg}$ per rat), the rats of the second group being simultaneously injected intraperitoneally with acetoacetate (200 $\mathrm{mg} / \mathrm{kg}$ body-weight), and the urine samples during the following $24 \mathrm{~h}$ were collected and analysed.

3. Acetoacetate-treated rats given tryptophan were found to excrete significantly greater amounts of kynurenine, hydroxykynurenine and xanthurenic acid than the corresponding control rats. There was no difference between the amounts of kynurenic acid excreted by the animals in the two groups.
\end{abstract}

Abnormal tryptophan metabolism has been noted in diabetic patients by Rosen, Maengwyn-Davies, Becker, Stone \& Freidenwald (1955), who observed increased urinary xanthurenic acid following oral administration of tryptophan in such cases. Xanthurenic acid and 3-hydroxykynurenine were reported to be present in the urine of diabetics by Kotake \& Tani (I953). McDaniel, Hundley \& Sebrell (I956) observed an impaired conversion of tryptophan into nicotinic acid in alloxan-diabetic rats, which were found to excrete more xanthurenic acid in their urine than normal rats when fed large amounts of tryptophan.

The intermediary fat metabolites, acetoacetate and $\beta$-hydroxybutyrate, which have been shown to induce hyperglycaemia and other diabetic symptoms in experimental animals (Nath \& Brahmachari, I944, I949a, b; Nath \& Chakrabarti, I950) were also reported to decrease urinary and blood nicotinic acid in rabbits on prolonged administration (Nath \& Chakrabarti, I953). We have reported that acetoacetate disturbs the conversion of tryptophan into nicotonic acid in rats (Shastri, Nayudu \& Nath, 1967). The present work was undertaken to study the effect of acetoacetate on urinary excretion of xanthurenic acid and other tryptophan metabolites in rats.

\section{EXPERIMEN TAL}

Male albino rats weighing 40-50 g each were used. The animals were fed on a basal nicotinic acid-deficient diet (Table $\mathrm{I}$ ) for a period of 3 weeks. Food and water were given ad lib. After 3 weeks, the animals were divided into two groups and placed in metabolic cages in groups of two, and basal $24 \mathrm{~h}$ samples of urine were obtained. Each rat was then given, by a stomach tube, roo $\mathrm{mg}$ L-tryptophan; the rats in the second group were simultaneously injected intraperitoneally with sodium acetoacetate 
(200 $\mathrm{mg} / \mathrm{kg}$ body-weight) and urine samples of both the groups during the following $24 \mathrm{~h}$ were collected. Indoxyl sulphate, anthranilic acid glucuronide, 0 -aminohippuric acid, acetylkynurenine, anthranilic acid and kynurenine were determined by the methods of Brown \& Price (1956). Hydroxykynurenine was determined by the method described by Brown (I957), kynurenic acid and xanthurenic acid by the procedure of Satoh \& Price (1958).

Table I. Composition $(\mathrm{g} / \mathrm{I} \circ 0 \mathrm{~g})$ of basal nicotinic acid-deficient diet

$\begin{array}{lc}\text { Sucrose } & 8 \mathbf{I} \cdot 8 \\ \text { Vitamin-free casein } & 9 \\ \text { Hawk-Oser salt mixture } & 4 \\ \text { Groundnut oil } & 5 \\ \text { L-Cystine } & 0 \cdot 2 \\ \text { B vitamins } & * \\ \text { Fat-soluble vitamins } & \dagger\end{array}$

* Per $100 \mathrm{~g}$ diet: thiamine $0.2 \mathrm{mg}$, riboflavine $0.5 \mathrm{mg}$, pyridoxine $0.25 \mathrm{mg}$, calcium pantothenate $2 \mathrm{mg}$, choline chloride $100 \mathrm{mg}$, inositol 10 $\mathrm{mg}$, biotin $0.01 \mathrm{mg}$ and folic acid $0.02 \mathrm{mg}$.

$\dagger$ Provided in the form of shark-liver oil fortified with vitamins $\mathrm{E}$ and $\mathrm{K}$ and dissolved in groundnut oil; given once a week by a dropper to provide approximately per rat per day: vitamin A 6 i.u., vitamin D 0.06 i.u., 2-methyl-1,4-naphthaquinone $0.04 \mathrm{mg}$, $\alpha$-tocopherol $0.5 \mathrm{mg}$.

\section{RESULTS}

The results are given in Table 2. Acetoacetate-treated rats given tryptophan were found to excrete considerably greater amounts of kynurenine, hydroxykynurenine and xanthurenic acid in their urines than the corresponding control rats. There was no significant difference between the urinary levels of kynurenic acid excreted by the rats of the two groups.

Table 2. Effect of an intraperitoneal injection of $200 \mathrm{mg}$ acetoacetate/per $\mathrm{kg}$ body-weight on urinary concentrations ( $\mu$ moles/rat per day) in rats on a nicotinic acid-deficient diet before and after administration of $100 \mathrm{mg}$ L-tryptophan by stomach tube

\section{Metabolite}

Indoxyl sulphate

Anthranilic acid glucuronide $\uparrow$

o-Amino hippuric acid

Acetylkynurenine and anthranilic acidf

Kynurenine

Hydroxykynurenine

Kynurenic acid

Xanthurenic acid

\begin{tabular}{lr}
\multicolumn{2}{c}{ Control group } \\
Before & \multicolumn{1}{c}{ After } \\
$5.8 \pm 1.7$ & $6.3 \pm 2 \cdot 1$ \\
$0.1 \pm 0.02$ & $0.5 \pm 0.02$ \\
$0.8 \pm 0.2$ & $2.0 \pm 0.05$ \\
$1 \cdot 1 \pm 0.3$ & $15.4 \pm 3.0$ \\
$0.3 \pm 0.01$ & $4.3 \pm 0.9$ \\
$0.4 \pm 0.2$ & $8.4 \pm 1.6$ \\
$0.8 \pm 0.2$ & $32.6 \pm 6.0$ \\
$0.4 \pm 0.2$ & $8.7 \pm 2.3$
\end{tabular}

* Significantly greater than the value for the control group $(P<0.05)$.

** Significantly greater than the value for the control group $(P<0.01)$.

+ Expressed as anthranilic acid.

$\ddagger$ Values are the sum of acetylkynurenine and anthranilic acid, expressed as acetylkynurenine.

\section{DISCUSSION}

The presence of higher amounts of kynurenine, hydroxykynurenine and xanthurenic acid and normal amounts of kynurenic acid in acetoacetate-treated rats suggests 
that there is no disturbance in the conversion of tryptophan into kynurenine and then into 3-hydroxykynurenine in such animals and that acetoacetate mainly affects the conversion of 3 -hydroxykynurenine into nicotinic acid, thus shunting the tryptophan metabolism into xanthurenic acid.

This change in the pattern of urinary metabolites is similar to that found in pyridoxine-deficient rats by Korbitz, Price \& Brown (I963). Kotake (1955) observed pyridoxine deficiency and an increase in urinary xanthurenic acid in rats fed large amounts of fat and tryptophan. Ketone bodies are produced in large amounts in high-fat feeding (Khanade $\&$ Nath, I960), and it has recently been observed by the authors that acetoacetate administration causes a depletion of pyridoxine in rats (unpublished results). It appears that the administration of acetoacetate disturbs tryptophan metabolism by depleting experimental animals of pyridoxine.

The authors wish to thank the Council of Scientific and Industrial Research, India, for financial assistance.

\section{REFERENCES}

Brown, R. R. (1957). F. biol. Chem. 227, 649.

Brown, R. R. \& Price, J. M. (1956). F. biol. Chem. 219, 985.

Khanade, J. M. \& Nath, M. C. (1960). Proc. Soc. exp. Biol. Med. 105, 566.

Korbitz, B. C., Price, J. M. \& Brown, R. R. (1963). F. Nutr. 80, 55.

Kotake, Y. (1955). F. Vitam. I, 73.

Kotake, Y. \& Tani, S. (I953). F. Biochem., Tokyo 40, 295.

McDaniel, E. G., Hundley, J. M. \& Sebrell, W. H. (I956). f. Nutr. 59, 407.

Nath, M. C. \& Brahmachari, H. D. (1944). Nature, Lond. 154, 487.

Nath, M. C. \& Brahmachari, H. D. (1949a). Indian F. med. Res. 37, 61.

Nath, M. C. \& Brahmachari, H. D. (1949b). Indian Ұ. med. Res. 37, 7 I.

Nath, M. C. \& Chakrabarti, C. H. (1950). Proc. Soc. exp. Biol. Med. 75, 326.

Nath, M. C. \& Chakrabarti, C. H. (1953). Proc. Soc. exp. Biol. Med. 82, 5.

Rosen, D. A., Maengwyn-Davies, G. D., Becker, B., Stone, H. H. \& Friedenwald, J. S. (1955). Proc. Soc. exp. Biol. Med. 88, 32 I.

Satoh, H. \& Price, J. M. (1958). F. biol. Chem. 230, 781.

Shastri, N. V., Nayudu, S. G. \& Nath, M. C. (1967). F. Vitam. 13, 47. 